\title{
The Analysis of Financial Risks of Real Estate in China
}

\author{
Wanqian Xie* \\ China Economics and Management Academy, Central University of Finance and Economics, \\ Beijing 100081, China. \\ luffyonlyforever@163.com
}

\begin{abstract}
This paper analyzed the status of China's real estate financial risks, and summarized the outstanding features of the real estate financial risks. The real estate financial risks will run through the whole process of China's industrialization and urbanization, while the possibility of evolving from a hint of financial risk to the global risks will increase occasionally; there are periodicity, conductivity, invisibility and controllability in the risks of real estate finance supported by traditional financial organizations and informal finance.
\end{abstract}

Keywords: Real estate; financial risks; real estate finance.

\section{Introduction}

After the housing system reform in 1998, the real estate in China developed rapidly, and had played an important role in economic growth. From a statistical perspective, real estate has already become one of the important pillar industries of national economy. In spite of the sign of cut in China's real estate market in 2014, according to the rules of the development of the urbanization, the development of urbanization and real estate industry are highly related, as long as the urbanization process is going, the real estate development trend will not change ${ }^{[1]}$. The rapid development of urbanization will certainly create a huge real estate market demand, and the important status of real estate in national economy and the trend of rapid development will remain unchanged.

With the pace of market-oriented reform of real estate in China, real estate finance in China presents a rapid development momentum. Real estate finance is the combination of real estate market and financial market, and is the link bridge of these two. Real estate finance has played a significant role in supporting the real estate industry development, and the healthy development of real estate financial market can also increase the capital fluidity ${ }^{[2]}$. The dependence of real estate market on real estate finance has greatly increased in multiple links such as production, circulation and consumption. But with the improvement of the exoteric extent of markets, and the imperfection of financial system, China's real estate can be easily influenced by foreign financial unrest.

In recent years, the development of China's real estate finance shows the characteristics of scale expansion. Because of the real estate finance is over-dependence on bank credit, the real estate financial risks are mainly concentrated in the commercial bank, and there are the signs of financial risks of real estate financial market in China ${ }^{[3]}$. In this paper, based on what has been discussed above, we analyzed the status and the outstanding features of China's real estate financial risks.

\section{The Status of China's Real Estate Financial Risks}

The real estate finance has satisfied the demand of both real estate investment and consumption, on one hand, it provides funds for real estate developers; on the other hands, it provides capital borrowing and lending for real estate customers. However, in the promotion of real estate development, the real estate finance in China also contains many kinds of risks. 


\subsection{Interest Rate Risk.}

Interest rate risk is caused by the variation of interest rate. The interest rate risk of real estate finance is the possibility of loss caused by interest rate variation in both supply and demand sides, mainly refers to the risks of commercial Banks. On one hand, the change of interest rate will affect the real estate consumers' expectations, which will increase the cost of the loan; on the other hand, loan interest rate changes will also affect the real estate development funds. Because most of the real estate development funds are received from the bank loan, the increase of loan interest will cause the increase of the real estate development cost, and reduce the investment of real estate development.

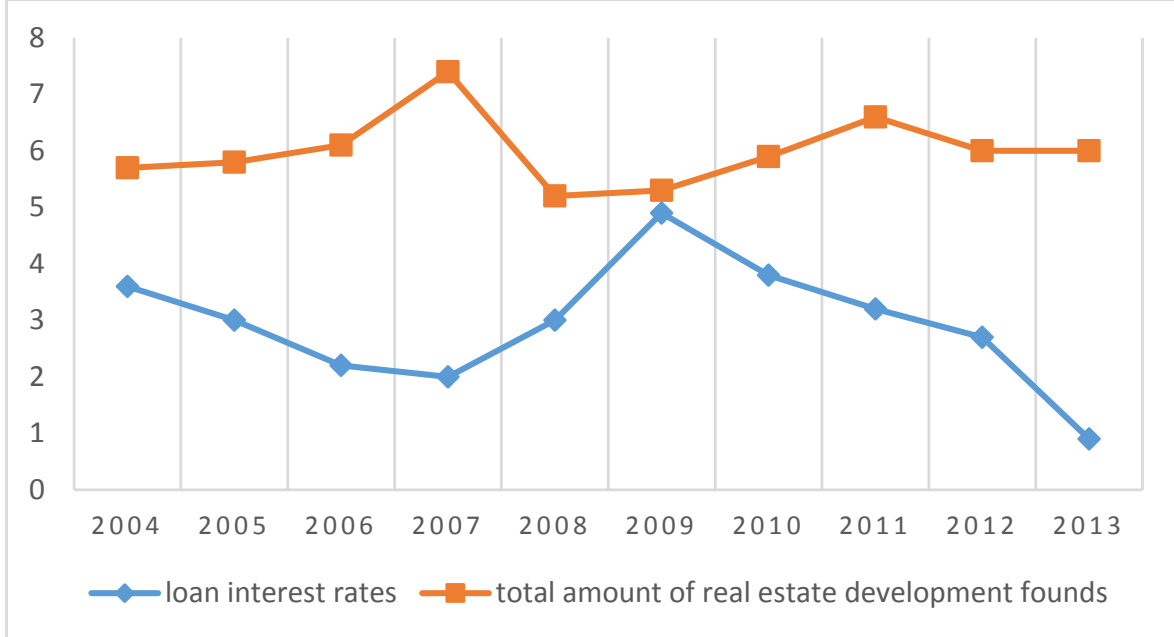

Figure 1 the volatility of loan interest rates and the total amount of real estate development founds from 2004 to 2013

In China, the influence of interest rate fluctuations to real estate finance is very significant. In real estate development funds, the volatility of bank loan interest rates and the total amount of real estate development founds is shown in figure 1. The fluctuation of bank loan interest rate which is influenced by the central bank's monetary policy, is in contrast to China's economic cycle. When the total real estate development funds has increased, the bank loan interest rate showed a trend of decline, and vice versa. And this trend is identical with the previous theoretical analysis. It proved that the fluctuation of interest rate can have a big impact on the real estate finance, the interest rate risk of real estate finance should not be underestimated.

\subsection{Exchange Rate Risk.}

The exchange rate risk in real estate financial market is the uncertainty of the real estate financial system caused by the volatility of exchange rate. It is mainly refers to the risk that the inflows and outflows of the hot money which caused by currency fluctuations in the field of real estate finance. In theoretical analysis, the change of exchange rates will not directly affect the domestic investment of real estate finance, but it will directly lead to the change of the amount of foreign investment in real estate financial market ${ }^{[4]}$.

In China, the exchange rate risk in China's real estate financial market is also prominent. The appreciation of the RMB caused a large number of hot money flow into China's real estate market, which raised China's real estate prices and expanded the degree of China's real estate bubble. However, once the RMB undervalued, the foreign investment withdraw, China's real estate prices will be plunged, which will inevitably bring China's real estate financial market huge uncertainty. 


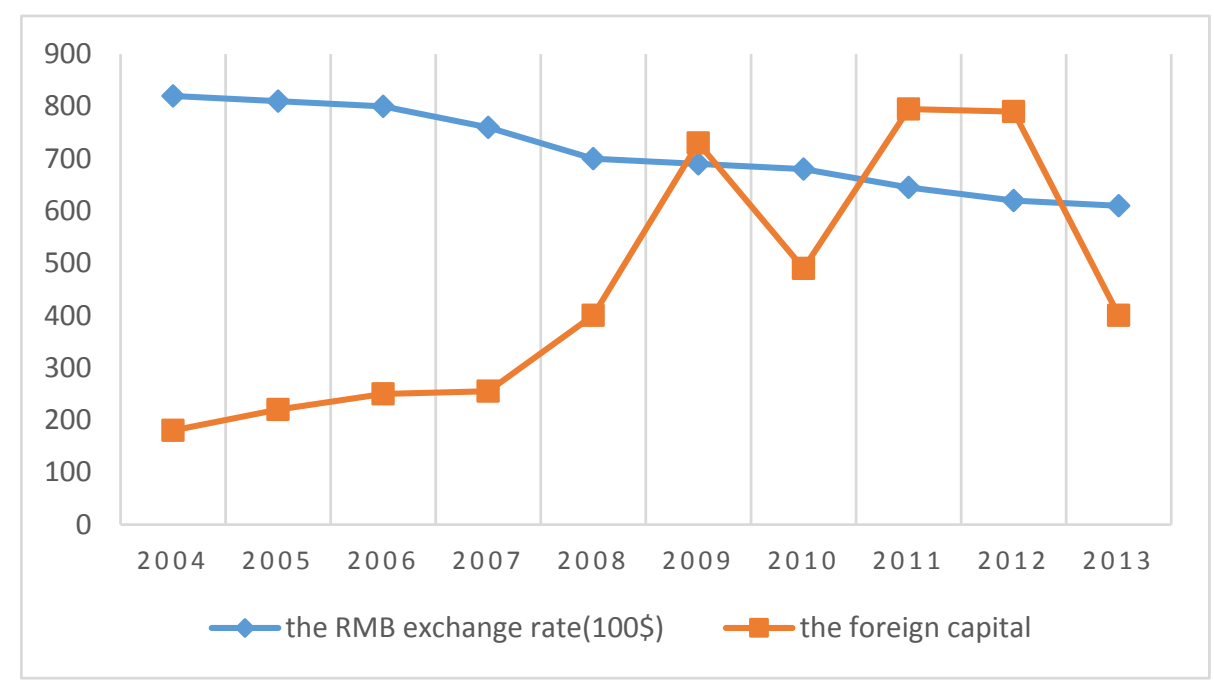

Figure 2 the RMB exchange rate and the foreign capital in China's real estate development investment from 2004 to 2013

Figure 2 shows the relationship between the RMB exchange rate and the foreign capital in China's real estate development investment. As shown in figure 2, in the 10 years from 2004 to 2013, especially during the continued appreciation in the RMB since 2005, the foreign capital in China's real estate development investment keeps rising, which means the appreciation of the RMB caused a large number of hot money flow into China's real estate market, which raised the risk of China's real estate finance.

\subsection{Credit Risk.}

The credit risk of real estate finance means that after borrowing from financial institutions, the real estate developers or buyer cannot timely payment because of their various reasons which caused the risk to the financial institutions and even the entire financial system. The credit risk is mainly caused by the information asymmetry between borrowers and lenders.

In China, $80 \%$ of the real estate development funds and land purchase cost are from the financial institutions, and more than $20 \%$ of all lending loans in financial institutions is given to the real estate industry. So the financial institutions take almost the entire risks of the real estate chain, including the credit risk. Researchers by using KMV model analyzed China's real estate development enterprise credit risk, and found out that China's real estate finance credit risk exists universality.

\subsection{Liquidity Risk.}

The liquidity risk in real estate finance is mainly refers to the increase of assets or the decrease of liabilities of commercial bank due to the real estate credit business, thus facing liquidity barriers which the commercial Banks can't avoid through liquid asset under reasonable cost benefit.

In China, the real estate finance has a distinguishing feature that the real estate developers' capital mainly comes from commercial Banks which gives big liquidity risk to commercial Banks. After the real estate loans are given out, due to the long construction period of real estate, the bank will not be able to withdraw money in a short time which will inevitably cause the short of cash. And the requirements of depositors withdraw will not be able to meet, leads to the imbalance of the structure of assets and liabilities of commercial Banks.

\subsection{Policy Risk.}

The policy risk refers to the uncertainty of real estate financial markets caused by the change of national macro-control policies. Policy risk is one kind of systematic risk, the financial main body cannot avoid it through investment portfolio ${ }^{[5]}$. Chinese government has been used the macro-control on the real estate industry since 1993. During the next 20 years, the frequency and strength of 
regulation continue to increase. Though have achieved certain results, the policy effects tend to be short-term, in the long term that could set a dangerous precedent for China's real estate market. When house prices fluctuated under the government regulation, the uncertainty of China's real estate financial markets also can be increased.

\section{The Features of China's Real Estate Financial Risks}

\subsection{Periodicity.}

As China's socialist market economic system is preliminary established, the growth of economic has great volatility. With the economic cycle continuous change through boom, recession, depression and recovery, real estate financial risks is cyclical change accordingly. Real estate financial institutions are engaged in business activities under the national macro policy, the interest rate policy and the tax policy have a significant effects on real estate financial institutions. The different combination of monetary and fiscal policy is constantly adjusted to adapt to the economic cycle, which affect the operation of the real estate financial market.

\subsection{High Conductivity and Systematicness.}

The high conductivity of China's real estate financial risks refers to the financial risks has high transmission speed and great influence. Since the real estate market reform in 1998, China's real estate industry gradually developed into a highly financialization industry. Because the large real estate investment scale and the outstanding scale effect, the conductivity of the real estate financial risks has been highly improved. The systematicness of China's real estate financial risks depend on the characteristics of the real estate industry. The financial risks not only exists in each participating body, and the exposure of the financial risk of any participation body will spread to other participants of financial chain.

\subsection{Invisibility and Controllability.}

The invisibility of real estate financial risks refers to the information asymmetry between the two sides lead to the risk is unknown by the lender, while the risk monitoring ability of the borrower is limited which caused the risk in the hidden state. As long as there is the existence of economic activity, the risks are inevitable. The greater the yield, the greater the risk. The controllability of real estate financial risks means that although the risks are objective existence, but can be controlled by strengthening professional management.

In addition to the characteristics analyzed above, there are some personalized features of China's real estate financial risks: the real estate financial risks through the process of industrialization and urbanization in China; the real estate financial risks are highly concentrated which increased the likelihood of the outbreak of systemic risk; and the real estate financial risks are closely related to the lags behind of China's financial market development.

\section{Conclusion}

In the rapid development of current Chinese real estate financial market, combining with the actual situation of China's real estate financial, we analyzed the status of China's real estate financial risks, and summarized the characteristics of financial risks in China. Through the theoretical and empirical analysis above, we can find that real estate finance can promoting economic growth, while at the same time, also contains certain financial risks. The financial risks of real state can have serious effects on the healthy development of the real estate market and the stability of the entire financial system. Therefore, we should pay a great attention to the risks of real estate finance, guard against the negative impact on macroeconomic. 


\section{References}

[1] Shu qingnian. Consideration on Real Estate Financial Innovation after the Outbreak of Sub-prime Crises [J]. South China Finance, 2008(9):10-14.

[2] T Yamashita. House Price Appreciation, Liquidity Constraints, and Second Mortgages [J]. Journal of Urban Economics, 2007, 62(3):424-440.

[3] Wang chunyan. study on china's real estate financial innovation [J]. Contemporary Economics, 2011(18):102-103.

[4] C M Reinhart, K S Rogoff. This Time is Different: A Panoramic View of Eight Centuries of Financial Crises[R]. National Bureau of Economic Research, 2008.

[5] T Kim, B Koo, M Park. Role of Financial Regulation and Innovation in the Financial Crisis [J]. Journal of Financial Stability, 2013, 9(4):662-672. 